\title{
肩腱板断裂の再手術例についての検討
}

\author{
熊本機能病院整形外科 \\ 浦 田 節 雄・米 満 弘之 \\ 中 島 英 親・高 橋 修一朗 \\ 錦 戸 悦 夫
}

\section{Experience of a Second Attempt at surgical Repair of a Failed Initial Rotator-Cuff Repair}

by

\section{Setsuo Urata, Hiroyuki Yonemitsu, Hidechika Nakashima, Shuichiro Takahashi and Etsuo Nishikido \\ Department of Orthopedic Surgery, Kumamoto Kinoh Hospital}

Four patients with four involved shoulders underwent a second attempt at repair of an initial rotator-cuff repair that had failed. Factors associated with the failure of the initial repair included inadequate measure of the cuff repair, massive ossification in the subdeltoid subacromial space and possibly inadequate post-operative rehabilitation program. We concluded that a secoud attempt at repair of an initial rotator-cuff repar was so pessimistic that we have to try the least treatment at an initial repair.

\section{はじめに}

腱板断裂の手術法については，まだ数多くの問題を 残している. 今回，われわれは，腱板断裂再手術例を 検討し，その原因及び対策について検討したので報告 する。

\section{対象及び結果}

1985年 6 月より1988年 9 月までの腱板断裂手術症例 は101症例109肩，うち再手術症例は 4 症例 4 肩である. 腱板の縫合に問題のあったと思われる症例が 2 例 2 肩, 手術後の職場復帰に問題があったもの 1 症例 1 肩, 術後 3 週目の肩の降下のリハビリテーションにて滑液 包内に骨化をきたした症例 1 例 1 肩であった。

\section{症例：48歳 男性 農業}

主訴：右肩痛

既往歴： 5 年前よりの端息

現病歴：喘息の薬の副作用にて失神し，右肩打撲, 右肩鎖関節脱臼にて，他医にて手術施行される．昭和
62年 5 月より右肩痛増強する.

関節造影にて滑液包内への造影剤の漏出あり（図1）, 昭和 62 年 6 月, 手術施行. 棘上筋の縦断裂であった. Zero-position ギプス固定を施行し，そのこよろり発 熱と右肩の痛みと腫脹が強くなった（表 1 ). 単純レン トゲンにて三角筋部に化骨形成をみた (図 2 )。骨シン チにて右肩の著明な集積像と術後 1 年目の造影所見に て腱板の広範囲断裂を示す（図 3 ). 昭和 63 年 4 月, 再 手術施行.

骨化部三角筋内には存在せず，三角筋下滑液包内に 形成されていた，骨化部分を摘出し，腱板は大腿筋膜 脹筋を使用し，tendon graft を施行，現在骨化の再発 はない(図 4 ).

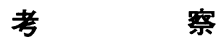

1984年, Cofield らは27例27肩の腱板断裂再手術例 について，その術後結果を発表している.

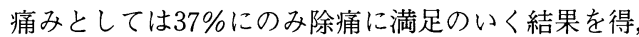
可動域や筋力の改善は得にくいといっている. 患者の 


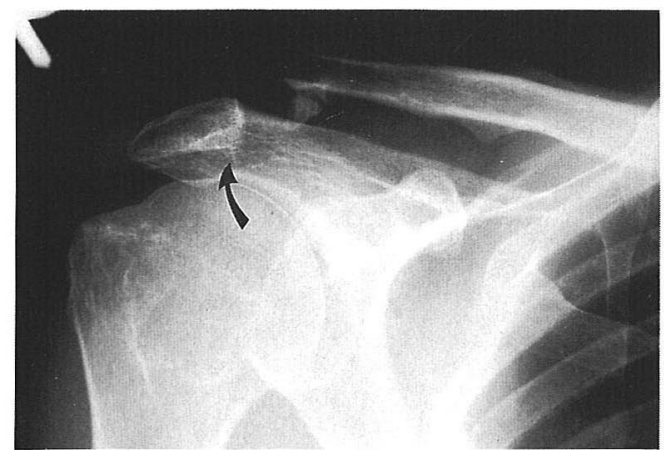

A ; 初診時単純レントゲン肩峰下の骨棘あり

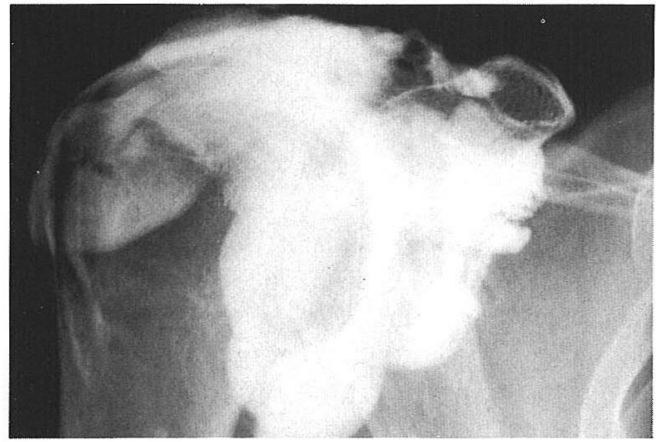

B ; 関節造影時 腱板断裂例

図 1 腱板断裂例

67\%に全体に満足のいく結果を得ているが，再手術の 効果に関しては，非観的であった（1）.12/3)5/11

我々の症例のうち, 腱板の修復に問題があったと思 われるものは，ギプス固定中脱臼した症例と不完全断 裂の症例とである.

これらの症例よりの教訓として, 前回, 本学会で発 表した，我々の腱板修復方法を現在用いている. 4)6)7)81 9) 10) 12) 13) 14

軟部組織と軟部組織を縫縮することにより，縫合部 の強度を得, 早期のリハビリテーションを可能として いる. また, arm at the sideでの内旋, 外旋の ten. sion をとりながら, 腱板を縫合することより, Zero-position 固定中の腱板の tension の片寄りをなくし， 脱臼も予防できるものと考える.

術後の職場復帰に関しては, 初回手術時に断裂の大 きさ, 腱板の状態, 縫合の方法, 患者の職場の状況な どを考虑し, 半年から 1 年を目安とするようにしてい る. 場合によっては職場を変えることも必要と考える.

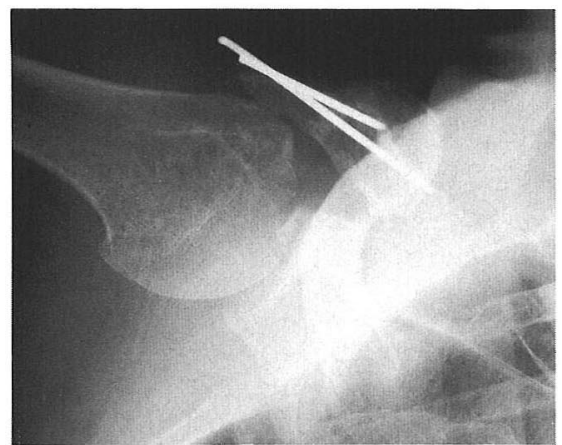

A ; 術後 2 週目

骨化はみられない

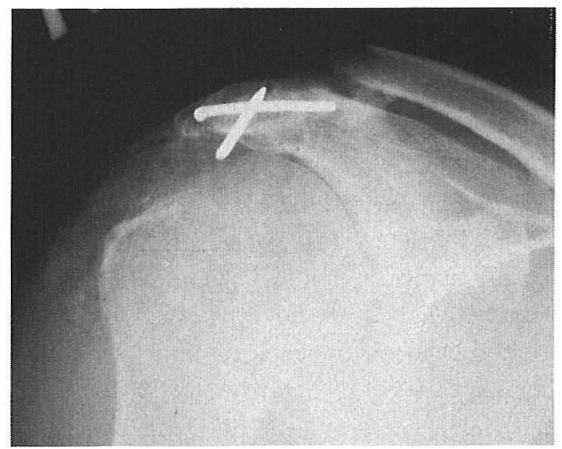

B ; 術後 5 週目 術後 3 週目より肩の降下を 施行し， 2 週目の状態 骨化像出現

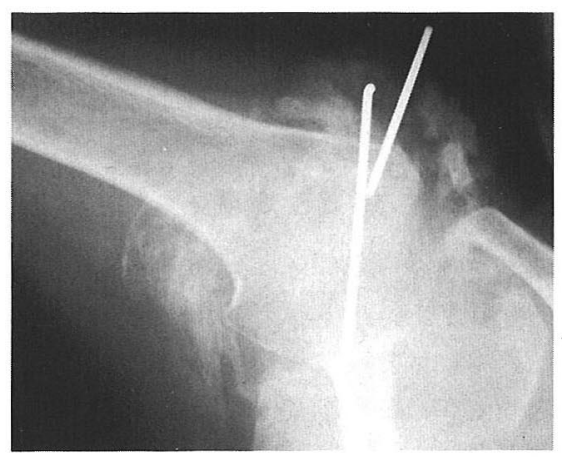

C ; 術後 8 週目 広範囲に骨化像出現

図 2 術後レントゲン像 
表 1 術後経過を示す

6 月

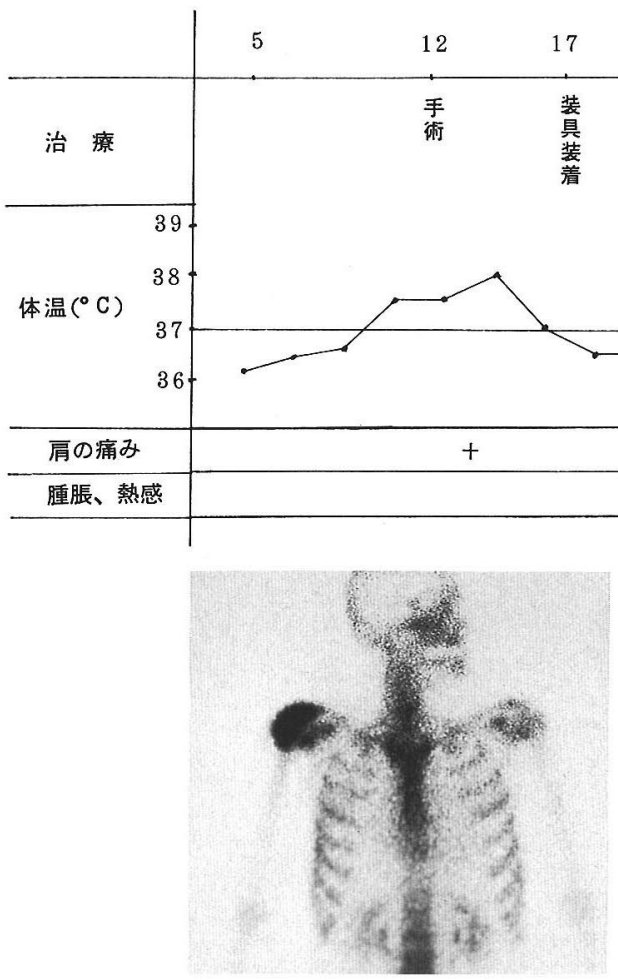

A 骨シンチにて右肩に集績を認める
7 月

\section{2}

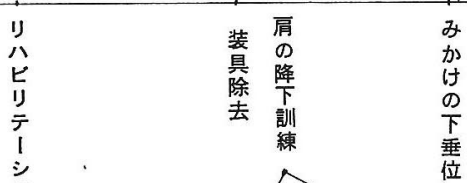
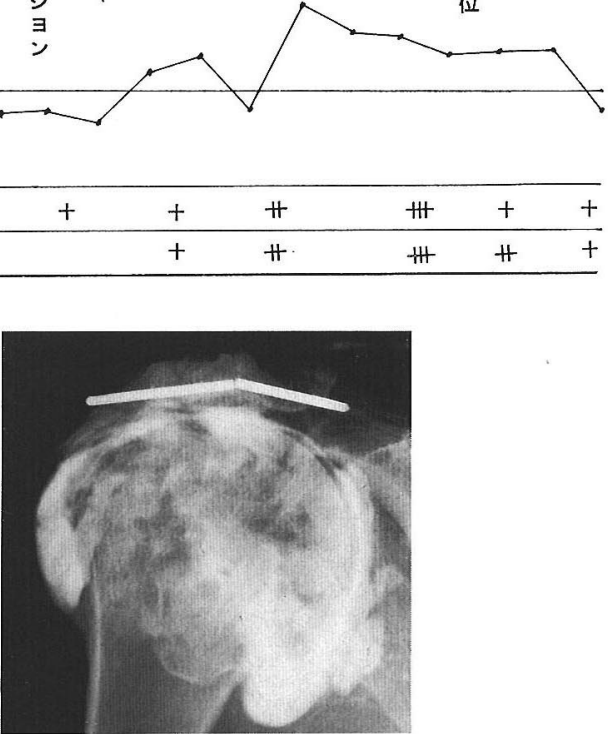

B 腱板の広範囲断裂像

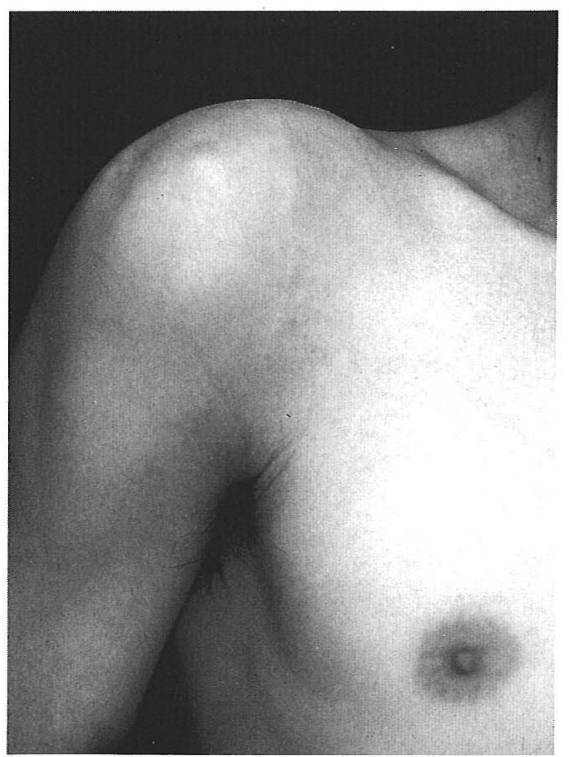

C 再手術時の右肩の状態

右肩に硬い腫瘤としてふれる

図 3 術後骨シンチ, 関節造影 


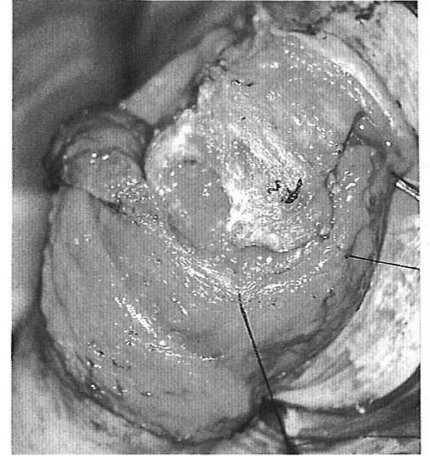

A 三角筋下に骨化部分をみる 滑液包内の骨化であった.

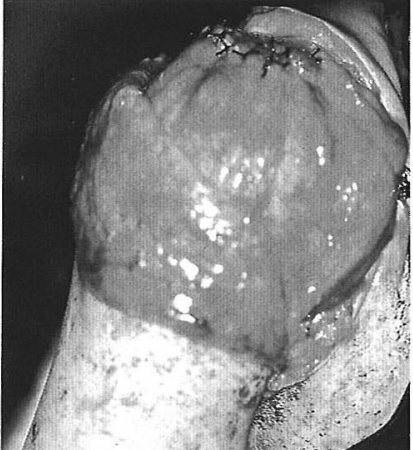

B 骨化部摘出後三角筋を 再縫着した状態

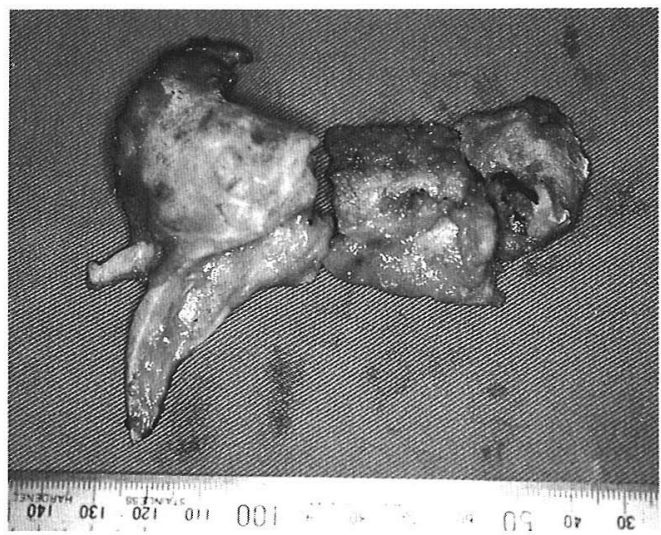

C 摘出した骨化部

図 4 術中所見

滑液包内の骨化は，術後 3 週よりの肩降下のリハビ リテーション中に発生していることより，リハビリテ ーションの重要性を痛感している，肩の降下を急ぐあ まり，Traumaticになり，骨化をひきおこしたもので はなかろうか。

我々はこの症例後,術後 1 週目より他動的にScapular placeにて肩の降下のExcise を施行し, 比較的スム 一ズな肩の降下と, 痛みの軽減を得ている.いずれに しろ, 腱板断裂の手術は, 初回の手術にて結果が決ま るといっても過言ではない. 初回手術での腱板修復に 最善を尽くすべきと考える.

$$
\text { ま と め }
$$

1. 腱板断裂再手術症例 4 例 4 肩につき，その原因と なった点について報告した.
2. 腱板手術後の職場復帰は, 術中の腱板の状態とと もに，断裂の種類などを考虑に入れて，少なくとも術 後 1 年間は重労働は控えるほうがよいと思われる.

3. 腱板手術後Zero-position より肩を降下してゆく リハビリテーションには十分な注意が必要と考える. 我々は手術後 1 週より他動的に肩の降下を行い, 早期 のリハビリテーションを施行し, 好結果を得ている. 4. 不完全断裂例は十分な術前の検査が必要であると ともに，術中は腱板断裂の部分を十分に確認すること が大切である。

\section{参 考 文 献}

1) Barton, N.J. : Arthrodesis of the shoulder for degenerative conditions. J. Bone and Joint Surg., 54-A : 1759-1764, 1972. 
2) Bush, L. F. : The Torn shoulder capsule. J. Bone and Joint Surg., 57-A : 256-259, 1975.

3) Cofield, R.H.: Tears of rotator cuff. in instructional course lectures, The american academy of orthopedic surgeouns. Vol. 30, pp. 258-273. St. Louis, C. V. Mosby, 1981.

4) Cofield, R. H. : Subscapular muscle transposition for repair of chronic rotator cuff tears., Gynec. and Obstet, $154: 667-672,1982$.

5) Cofield, R.H. and Briggs, B.T.: Glenohumeral arthrodesis. Operative and Long-Tearm Functional Results. J. Bone and Joint Surg., 61-A : 668-667, July 1979.

6) Debeyre, J., Patte, D. and Elmelik, E.: Repair of ruptures of the rotator cuff of the shoulder.

With a note on advancement of the supraspinatus muscle. J. Bone and Joint Surg., 47-B (1):3642, 1965.

7) Godsil, R. D., Jr. and Linscheid, R. L. : Intratendinous defects of the rotator cuff. Clin. Orthop., $69:$ 181-188, 1970.

8) Heikel, H. V. A.: Rupture of the rotator cuff of the shoulder. Experiences of surgical treatment.
Acta. Orthop. Scandinavica, $39:$ 477-492, 1968.

9) Neer, C. S., II : Anterior acromioplasty for the chronic impingement syndrome in the shoulder. A preliminary report. J. Bone and Joint Surg., 54-A : 51-50, Jan. 1972.

10) Neer, C. S. II and Marberry, T. A.: On the disadvantages of radical acrominectomy. J. Bone and Joint Surg., 63-A : 416-419, March 1981.

11) Samilson, R. L. and Binder, W. F. : Symptomatic full thickness tears of the rotator cuff. An analysis of 292 shoulders in 276 patients. Orthop. Clin. North America, $6: 449-466,1975$.

12) Weiner D. S. and MacNab, I. : Ruptures of the rotator cuff: Follow-up evaluation of operative repairs. Canadian J. Surg., 13:219-227, 1970.

13) Wolfgang, G. L. : Surgical repair of tears of the rotator cuff of the shoulder. Fractors influencing the results. J. Bone and Joint Surg., 56-A : 14-26, Jan. 1974.

14) Wolfgang, G. L. : Rupture of the musculotendinous cuff of the shoulder. Clin. Orthop., $134: 230-243$, 1978. 